\title{
Letter
}

\section{Cytokines in the colon of a patient with Behçet's disease Jasper H Kappen ${ }^{1}$, Willem A Dik², Gemma M Dingjan², Paul L van Daele ${ }^{1,2}$, Herbert Hooijkaas², $P$ Martin van Hagen ${ }^{1,2}$ and Jan A van Laar ${ }^{1,2}$}

\author{
'Department of Internal Medicine, Clinical Immunology Section, Erasmus MC, University Medical Center, room D419, 's Gravendijkwal 230, 3055CE, \\ Rotterdam, The Netherlands \\ 2Department of Immunology, Erasmus MC, University Medical Center, room D419, ‘s Gravendijkwal 230, 3055CE, Rotterdam, The Netherlands
}

Corresponding author: Jan AM van Laar, j.vanlaar@erasmusmc.nl

Published: 27 August 2009

Arthritis Research \& Therapy 2009, 11:412 (doi:10.1186/ar2784)

This article is online at http://arthritis-research.com/content/11/3/412

(c) 2009 BioMed Central Ltd

See related research by Cañete et al., http://arthritis-research.com/content/11/1/R1 7

We read with interest the article by Cañete and colleagues [1] in a recent issue of Arthritis Research \& Therapy, in which they describe cytokine patterns of inflamed joints from patients with Behçet's disease (BD). The authors show that neutrophils and T lymphocytes are involved in a Th1-skewed inflammatory pattern expressed by elevations of interferongamma (IFN- $\gamma$ ), tumor necrosis factor-alpha (TNF- $\alpha$ ), and interleukin-2 (IL-2). Also, increased levels of IL-4, IL-10, and IL-17 were observed. We would like to add to these observations our data showing a similar cytokine profile in the colon of a patient with BD.

A 37-year-old BD patient with severe colitis failed to respond to traditional immunosuppressive treatment. Steroids were contraindicated because of a previous retinal serosal ablation, probably induced by prednisone. TNF blockage initially successfully reduced the severity of the colitis, but relapses occurred. Variation of different TNF blockers (etanercept, infliximab, and adalimumab) could not permanently resolve the intestinal complaints. Antibodies against infliximab or adalimumab were not detected. Eventually, highdose infliximab $(10 \mathrm{mg} / \mathrm{kg})$ and intravenous immunoglobulins (IVIGs) led to disease regression facilitating a hemicolectomy. Thereafter, the patient's condition improved significantly and IVIGs were terminated while TNF blockage was continued.

Cytokines were evaluated in the resected colon by analyzing mRNA expression levels of cytokine genes as previously described [2]. Because of the extensive prior treatment, the patient served as an internal control. Intestinal inflammation was patchy, and the observed difference between healthy and diseased tissues was confirmed microscopically. The mRNA expression of cytokines in diseased colon is presented relative to that of healthy colon and can be seen as
Figure 1

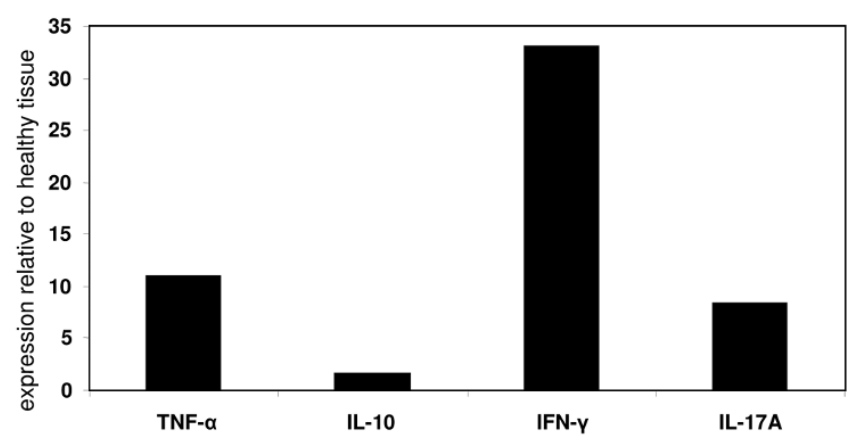

Relative mRNA expression of cytokine genes in affected colonic tissue of a patient with Behçet's disease. Diseased colonic tissue and healthy colonic tissue from the same patient were analyzed. IFN- $\gamma$, interferongamma; IL, interleukin; TNF, tumor necrosis factor.

a reflection of intramural cytokines (Figure 1). Like Cañete and colleagues, we observed a Th1- and Th17-skewed pattern (elevated IFN- $\gamma$ and TNF- $\alpha$ and elevated IL-17A, respectively). We could not demonstrate elevation of IL-10, possibly because our patient was intensively treated and the colon environment is not sterile.

The immunopathology of BD remains fascinating and highly relevant to the development of future immune-directed therapy. Since the successful introduction of TNF blockers, it became apparent that Th1-cytokines might be key players in the immunopathology of BD, emphasizing the importance of cytokine studies $[3,4]$. Cañete and colleagues [1] have highlighted the importance of tissue evaluation in cytokine studies. In this light, our data add to their observations that, 
in colonic tissue of a BD patient, IFN- $\gamma$, TNF- $\alpha$, and IL-17A appear to be key cytokines, even in a treated patient.

\section{Competing interests}

The authors declare that they have no competing interests.

\section{References}

1. Cañete JD, Celis R, Noordenbos T, Moll C, Gómez-Puerta JA, Pizcueta P, Palacin A, Tak PP, Sanmartí R, Baeten D: Distinct synovial immunopathology in Behçet disease and psoriatic arthritis. Arthritis Res Ther 2009, 11:R17.

2. Dik WA, Nadel B, Przybylski GK, Asnafi V, Grabarczyk P, Navarro JM, Verhaaf B, Schmidt CA, Macintyre EA, van Dongen JJ, Langerak AW: Different chromosomal breakpoints impact the level of LMO2 expression in T-ALL. Blood 2007, 110:388-392.

3. Yazici H, Fresko I, Yurdakul S: Behcet's syndrome: disease manifestations, management, and advances in treatment. Nat Clin Pract Rheumatol 2007, 3:148-155.

4. van Laar JA, Missotten T, van Daele PL, Jamnitski A, Baarsma GS, van Hagen PM: Adalimumab: a new modality for Behçet's disease? Ann Rheum Dis 2007, 66:565-566. 